\title{
The molecular characteristics of colorectal cancer: Implications for diagnosis and therapy (Review)
}

\author{
HA THI NGUYEN ${ }^{1}$ and HONG-QUAN DUONG ${ }^{2}$ \\ ${ }^{1}$ Center for Molecular Biology, Institute of Research and Development, Duy Tan University, Danang 550000; \\ ${ }^{2}$ Department of Cancer Research, Vinmec Research Institute of Stem Cell and Gene Technology, Hanoi 100000, Vietnam
}

Received September 21, 2017; Accepted February 22, 2018

DOI: $10.3892 / \mathrm{ol} .2018 .8679$

\begin{abstract}
Colorectal cancer (CRC) results from the progressive accumulation of multiple genetic and epigenetic aberrations within cells. The progression from colorectal adenoma to carcinoma is caused by three major pathways: Microsatellite instability, chromosomal instability and $\mathrm{CpG}$ island methylator phenotype. A growing body of scientific evidences suggests that $\mathrm{CRC}$ is a heterogeneous disease, and genetic characteristics of the tumors determine their prognostic outcome and response to targeted therapies. Early diagnosis and effective targeted therapies based on a current knowledge of the molecular characteristics of CRC are essential to the successful treatment of CRC. Therefore, the present review summarized the current understanding of the molecular characteristics of CRC, and discussed its implications for diagnosis and targeted therapy.
\end{abstract}

\section{Contents}

1. Introduction

2. Molecular basis of CRC

3. Clinical implication of the molecular genetics of CRC

4. Conclusion and future perspectives

Correspondence to: Dr Ha Thi Nguyen, Center for Molecular Biology, Institute of Research and Development, Duy Tan University, 03 Quang Trung, Danang 550000, Vietnam

E-mail: nguyenthiha23@dtu.edu.vn

Dr Hong-Quan Duong, Department of Cancer Research, Vinmec Research Institute of Stem Cell and Gene Technology, 458 Minh Khai, Hanoi 100000, Vietnam

E-mail: quanvspt@gmail.com

Key words: colorectal cancer, chromosomal instability, microsatellite instability, $\mathrm{CpG}$ island methylator phenotype, molecular characteristics, early diagnosis, targeted therapy

\section{Introduction}

Despite improvements in early detection and treatment method in recent years, colorectal cancer $(\mathrm{CRC})$ remains the third most frequent and the fourth leading cause of cancer-associated mortalities worldwide $(1,2)$. Approximately $65 \%$ of CRC cases are sporadic with no family history or apparent genetic predisposition (3). The remaining cases are familial, arising from moderately penetrant inherited susceptibility, possibly interacting with environmental factors $(3,4)$.

$\mathrm{CRC}$, like numerous other solid tumors, is a heterogeneous disease in which different subtypes may be distinguished by their specific clinical and/or molecular features. The majority of sporadic CRCs $(\sim 85 \%)$ exhibit chromosomal instability (CIN), with changes in chromosome number and structure (5-8). These changes include gains or losses of chromosomal segments, chromosomal rearrangements, and loss of heterozygosity ( $\mathrm{LOH})$, which results in gene copy number variations (CNVs) (5-8). These alterations affect the expression of tumor-associated genes, and/or genes that regulate cell proliferation or cell cycle checkpoints, which, in turn, may activate pathways essential for CRC initiation and progression $(9,10)$. The remaining sporadic cases $(\sim 15 \%)$ have high-frequency microsatellite instability (MSI) phenotypes. However, hereditary CRC has two well-described forms: Familial adenomatous polyposis (FAP) $(<1 \%)$ patients inherit a mutated copy of the adenomatous polyposis $(A P C)$ gene, whereas hereditary non-polyposis colorectal cancer (HNPPC, or Lynch syndrome) (1-3\%) is characterized by MSI, a consequence of a defective DNA mismatch repair (MMR) system (11). The other forms of hereditary CRC include a rare syndrome called hamartomatous polyposis syndrome $(<1 \%)$ and the common inherited cases caused by less penetrant inherited mutations (32\%) (3).

Sequential acquisition of genetic and epigenetic alterations is well defined, and confirmed to drive the initiation and progression of adenomas to carcinomas in sporadic and inherited forms of CRC (12-14). Generally, CRC formation begins with the transformation of a normal colorectal epithelium to a benign adenoma, and then progresses through the stepwise accumulation of multiple genetic and epigenetic aberrations, subsequently leading to invasive and metastatic tumors (12-14). This process may take years to decades to escape the multiple regulatory layers of the cells and to fully 
develop (Fig. 1) (13,15). There are three major pathways associated with $\mathrm{CRC}$ pathogenesis, namely: CIN, MSI and $\mathrm{CpG}$ island methylator phenotype (CIMP) (16).

The extent to which cancer has spread at the time of diagnosis is described as its stage. Currently, CRC staging is primarily based on the tumor-nodes-metastasis (TNM) system proposed by the American Joint Committee on Cancer (17). The survival rate of patients with CRC largely depends on the stage at which tumor is first diagnosed and varies between stages. For example, the 5-year-survival rate for patients with stage I colon cancer is $93.2 \%$, which drops to $8.1 \%$ for patients with stage IV (17). Although TNM is currently the most common CRC staging system, and an important basis to determine the treatment method and assessing prognosis, it is not a reliable tool for prediction and prognosis. Particularly, CRC patients with similar histopathology may have completely different progression and outcome depending on their genetic and epigenetic background (18). Thus, understanding the molecular pathways underlying the initiation and development of CRC is essential to identify novel molecular biomarkers for diagnosis and prognosis, thereby improving the outcome. The present review summarized the current knowledge of the genetic and epigenetic integrity, the consequences of the DNA MMR machinery associated with CRC, and the role of molecular characterization in early diagnosis and in the treatment of CRC.

\section{Molecular basis of CRC}

CIN pathway. The average rate of genomic mutation in normal human cells is estimated to be $\sim 2.5 \times 10^{-8}$ mutations/nucleotide/generation $(19,20)$. However, this rate is higher in cancer cells due to the sequential accumulation of multiple mutations during cell divisions forming a so-called 'mutator phenotype' (21). Accordingly, mutations in MMR genes, genes that regulate cell cycle checkpoints, and/or cellular responses may elevate mutation rates to the level commonly observed in human tumors (21). The 'mutator phenotype' may have various manifestations, including point mutations, CIN, MSI, CIMP and LOH (21).

CIN appears to be the most common type of genetic instability in CRC, observed in $85 \%$ of adenoma-carcinoma transitions (5-7). CIN refers to a high rate of gains or losses of whole, or large portions of chromosomes. This leads to karyotypic variability from cell to cell that consequently forms an aneuploidy, sub-karyotypic amplification, chromosomal rearrangement, and a high frequency of $\mathrm{LOH}$ at tumor suppressor gene loci $(5,6)$. In addition, CIN tumors are recognized by the accumulation of mutations in specific oncogenes, including KRAS proto-oncogene GTPase (KRAS) and B-Raf proto-oncogene serine/threonine kinase $(B R A F)$, and tumor suppressor genes, such as $A P C$ and tumor protein p53 (TP53), thereby contributing to CRC tumorigenesis $(6,10)$. The multistep genetic model of colorectal carcinogenesis proposed by Fearon and Vogelstein is now widely accepted, and used as a paradigm for solid tumor progression (12). According to this model, inactivation of $A P C$ occurs as the first event, followed by oncogenic KRAS mutations in the adenomatous stage, and eventually, deletion of chromosome $18 \mathrm{q}$ and inactivation of the tumor-suppressor gene TP53 on chromosome $17 \mathrm{p}$ occur during the transition to malignancy (Fig. 1) (12,22-25).

Array-based comparative genomic hybridization and single nucleotide polymorphism techniques have enabled scientists to effectively determine CNVs in the entire human genome with higher resolution. Although the allelic loss of all chromosomal arms has been detected in certain tumors, its frequency varies considerably, and only a few of them are highly recurrent in $\mathrm{CRC}$, including losses at chromosomal arms 1p, 5q, 8p, 17p, 18p, 18q, 20p and 22q (26-31). A high-frequency allelic loss at a specific chromosomal region denotes the presence of a candidate tumor-suppressor gene, including $A P C$ on chromosome $5 \mathrm{q}$, TP53 on chromosome $17 \mathrm{p}$, DCC netrin 1 receptor $(D C C)$, SMAD family member (SMAD2 and SMAD4) on chromosome $18 \mathrm{q}$ (31). In contrast, a gain of chromosomal material suggests the presence of the potential oncogenes or genes that favor cell growth or survival. In CRC, gains at chromosome 7, and chromosomal arms 1q, 8q, 12q, 13q and 20q have been repeatedly reported by different research groups (26-31). It was reasoned that these chromosomal changes are associated with a gain and loss of function of tumor-associated genes offering mutated cells growth and survival advantages, leading to progressive conversion of normal cells into cancer cells $(32,33)$. However, the gains/losses of chromosomal materials generally span a large region and comprise a large number of genes making identification of target genes challenging.

In the field of stem cell research, genetic analysis of human embryonic stem cell (hESC) lines, a pluripotent cell type that shares numerous characteristics with cancer cells, has also revealed multiple CNVs, and few of them are also recurrent, including losses of chromosomal band 18q21qter, and whole or partial gains of chromosomes 1, 12, 17 and 20 (34,35). Notably, $20 q 11.21$ amplification was identified in $>20 \%$ of the screened hESC lines (36). Previously, BCL2 like 1 (BCL2L1), which is located in the smallest common chromosomal region of gain and regulates the mitochondrial apoptotic pathway, has been confirmed as the key-driver gene of this amplification $(37,38)$. Accordingly, the overexpression of Bcl-xL, an anti-apoptotic isoform of BCL2L1 has offered cells a survival advantage by preventing apoptosis $(37,38)$. Overexpression of this gene may also be responsible for the gain of $20 \mathrm{q}$ in various human cancer types (39).

Losses of $18 q$. Allelic loss at chromosome $18 \mathrm{q}$ is detected in $\sim 70 \%$ of primary CRC in the late carcinogenic process $(29,31,40,41)$, and is considered as a poor prognosis marker for survival in patients with CRC $(42,43)$. The high frequency of allelic deletions involving chromosome $18 \mathrm{q}$ suggests the presence of candidate tumor-suppressor genes whose inactivation may serve a significant role in CRC, including DCC, SMAD2 and SMAD4 (12,25,44). DCC, located in the chromosome band $18 \mathrm{q} 21.2$, encoding a component of the neutrin-1 receptor, was proposed as a putative tumor-suppressor gene (45). However, much of the reported data on the loss and inactivation of $D C C$ is circumstantial and fails to provide conclusive evidence that $D C C$ functions as a tumor-suppressor gene (46). Furthermore, to the best of our knowledge, there is no evidence that germline mutations of $D C C$ serve a role in heritable cancer; and few somatic mutations in $D C C$ have been reported in CRC (46). The presence 
Chromosomal instability (CIN)

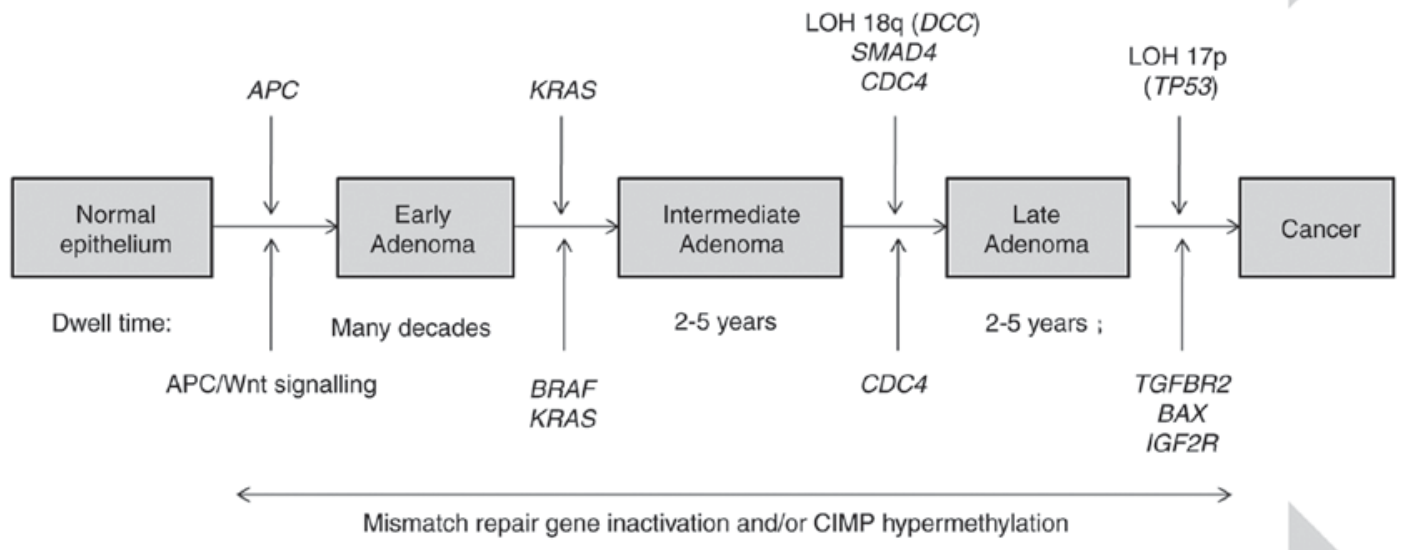

Microsatellite instability (MSI)

Figure 1. Colorectal adenoma-carcinoma sequence. The APC mutation is the first step transforming normal colorectal epithelium to adenoma. The adenoma-carcinoma sequence is caused by three major pathways: CIN, MSI and CIMP. CIN, Chromosomal instability; MSI, microsatellite instability; CIMP, CpG island methylator phenotype; $A P C$, adenomatous polyposis; KRAS, KRAS proto-oncogene GTPase; $B R A F$, B-Raf proto-oncogene serine/threonine kinase; TP53, tumor protein 53; LOH, loss of heterozygosity; HNPPC, hereditary non-polyposis colorectal cancer; $M L H 1$, mutL homolog 1; MSH2, mutS homolog 2; DCC, DCC netrin 1 receptor; TGFBR, transforming growth factor- $\beta$ receptor; BAX, BCL2 associated X apoptosis regulator; IGF2R, insulin like growth factor 2 receptor; $C D C 4$, cell division control protein 4.

of two other well-established tumor suppressor genes, SMAD2 and $S M A D 4$ in the region of loss also challenges the function of $D C C$ as a tumor-suppressor gene $(47,48)$. In fact, SMAD2 and SMAD4 genes are localized in $18 \mathrm{q} 21.1$, the common region of loss of $18 \mathrm{q}$ in CRC (25). These SMAD genes encode downstream signal transducers for transforming growth factor- $\beta(T G F-\beta)$, and their alterations may confer resistance to $T G F-\beta$ and contribute to tumorigenesis (49). SMAD4 was identified to be inactivated in $\sim 60 \%$ of pancreatic cancer (50). However, the frequency of SMAD4 and SMAD2 somatic mutations is relatively low in CRC (51-53). Nevertheless, smaller regions of loss, which exclude $S M A D 2$ and $S M A D 4$, have been reported in head and neck squamous cancer (54). In addition, their gene expression is retained in CRC with LOH of 18q (46). Taken together, these observations suggest that SMAD2 and SMAD4 are unlikely to constitute the major chromosome $18 \mathrm{q}$ target for inactivation in $\mathrm{CRC}$, and that other tumor suppressor genes besides the $D C C$ and $S M A D$ genes may be the target for chromosome $18 \mathrm{q}$ loss.

$A P C / \beta$-catenin. Activation of the Wnt signaling pathway via mutation of the $A P C$, a multi-functional tumor-suppressor gene on $5 q 22.2$, is essential and the earliest event in the development of CRC (55). APC protein is a key component of the $\beta$-catenin destruction complex involved in the degradation and suppression of the $\mathrm{Wnt} / \beta$-catenin signaling pathway (56). Mutant $A P C$ disrupts the formation of the destruction complex leading to stabilization and accumulation of $\beta$-catenin protein in the cytoplasm. Accumulated $\beta$-catenin protein is translocated to the cell nucleus where it forms complexes with $T C F / L E F$, and induces overactivation of Wnt downstream effectors that, in turn, promote the proliferation, migration, invasion and metastasis of cancerous cells (57). The same outcome is also observed with mutations in $\beta$-catenin (58) and AXIN2 (57), but to a lesser extent. Notably, mutations in AXIN2 have been reported in CRC with MSI only (59).

$A P C$ mutations or allelic losses have been identified in $\sim 90 \%$ of patients with CRC (60). Germline mutations in APC are responsible for FAP (15), while somatic mutations and/or allelic deletions of $A P C$ are described in sporadic CRC (61). The $A P C$ gene may also be epigenetically inactivated through promoter hypermethylation that has been identified in $18 \%$ of primary colorectal carcinoma and adenoma cases (62).

TP53. TP53 is a tumor-suppressor gene located on the short arm of chromosome 17, which is commonly lost in colorectal carcinoma (40). TP53 has been defined as the 'guardian of the genome' because it encodes a transcription factor that regulates the transcription of hundreds of genes involved in different processes, including DNA repair, cell cycle arrest, senescence, apoptosis and metabolism in response to a variety of the stress signals (63). Upon DNA damage, for example, TP53 induces cell cycle arrest at the $G_{1}$ or $G_{2}$ phase, or triggers apoptosis when the damage is too severe and irreparable (64). Loss of TP53 function, therefore, contributes to the propagation of damaged DNA to daughter cells.

TP53 alteration is the hallmark of human tumors, and the status of TP53 mutation is associated with the progression and 
outcome of sporadic CRC (65). Particularly, TP53 loss of function has been reported in $50-75 \%$ of CRC cases, much higher compared with that in adenoma, indicating its role in the transition from an adenoma to carcinoma $(66,67)$. To date, the majority of the TP53 mutations reported in CRC are missense mutations that substitute AT for GC (68). Liu and Bodmer (69) have analyzed TP53 mutations and their expression in 56 CRC cell lines, and reported a relatively high frequency of TP53 mutations $(76.8 \%)$, in which missense mutations accounted for $47.83 \%$ and point mutations that are transitions at $\mathrm{CpG}$ sites accounted for $37.5 \%$. These mutations render an inactive protein with an abnormally long half-life that is detectable by immunohistochemistry (70).

$K R A S$. The KRAS gene belongs to the RAS gene family involved in signaling pathways that regulate cellular proliferation, differentiation or survival. KRAS is a membrane-bound GTP/GDP-binding protein with intrinsic GTPase activity and is expressed in the majority of human cells. The switch between its active GTP-bound state and the inactive GDP-bound state is regulated by GTPase-activating proteins and guanine nucleotide exchange factors (71). The KRAS mutations impair the intrinsic GTPase activity of KRAS, causing the accumulation of the KRAS proteins at the GTP-bound active state, eventually resulting in the constitutive activation of the downstream proliferative signaling pathways (72).

Oncogenic mutations in the RAS gene have been identified in $\sim 30 \%$ of all human tumors (73), in which mutations in $K R A S$ accounted for $\sim 85 \%$, NRAS proto-oncogene GTPase $(N R A S)$ for $\sim 15 \%$, and HRas proto-oncogene GTPase (HRAS) for $<1 \%$ (74-76). The high frequency of KRAS mutations and its appearance at a relatively early stage in tumor progression suggest a causative role of KRAS in human tumorigenesis. Several studies have reported an association between KRAS mutations, and poor prognosis of CRC $(77,78)$, and lung $(79,80)$ and liver $(81)$ metastasis. In contrast, several other studies reported that KRAS mutations were strong independent predictors of survival in patients with CRC (80-82). These contradictory findings may be explained by the differences in the distribution of specific KRAS mutations, stage at diagnosis or other characteristics. KRAS mutations have emerged as an important predictive marker of resistance to anti-epidermal growth factor receptors $(E G F R)$ agents, including panitumumab and cetuximab (83-86).

Activating KRAS mutations have been identified in $35-45 \%$ of CRC cases (40,80,87-89), and primarily occur in codon 12 and $13(75,89)$. The most frequent changes observed in these codons are the substitution of glycine for aspartate (p.G12D, p.G13D) (90). The mutation rates of $N R A S$, in contrast, are lower (1-3\%) and activating mutations of HRAS has not been detected in CRC $(40,91,92)$. Previously, pyrosequencing of $K R A S, B R A F$ and phosphatidylinositol-4,5-bisphosphate 3-kinase catalytic subunit $\alpha$ revealed that $53.8 \%$ of patients exhibit a KRAS mutation in codons 12 or 13 , of which $57.9 \%$ were c.38G $>$ A (pG13D), and $22.2 \%$ were c35G $>$ T (p.G12V) mutations (93).

MSI. Another type of genomic instability is MSI, a typical characteristic of cancerous cells, occurring in 15-20\% of sporadic CRC and in $>95 \%$ of HNPPC. Microsatellites are repetitive DNA sequences consisting of tandem repeats, usually between one to five base pairs. Patients with MSI phenotype exhibit a high frequency of replication errors, particularly in repetitive DNA sequences, primarily due to the slippage of the DNA polymerase (94). The progressive insertion/deletions of nucleotides within the microsatellite sequences result in the appearance of longer or shorter alleles compared with those detected in the normal cells of the same individual $(95,96)$.

To access the MSI status of a cancer, a standard panel of five microsatellite markers, including two mononucleotide (BAT26 and BAT25) and three dinucleotide (D2S123, D5S346, and D17S250) repeats, has been recommended according to the Bethesda Guidelines (97). Tumors are then classified based on the number of microsatellites exhibiting instability. Particularly, tumors are classified as MSI high (MSI-H) when $\geq 30 \%$ of the markers exhibit instability; those with $<30 \%$ markers exhibiting instability are defined as MSI low, and those with no apparent instability are microsatellite stable (MSS) $(97,98)$.

It is now accepted that MSI is associated with post-replicative DNA MMR deficiency, primarily involving mutL homolog 1 (MLHI) and mutS homolog 2 (MSH2) (94,99-101). Impairment of MMR genes can occur by either mutational inactivation or by epigenetic inactivation through $\mathrm{CpG}$ island methylation of the promoter of the genes. Loss or insufficiency of MMR activity leads to replication errors with an increased mutation rate and a higher potential for malignancy. In MSI-H gastric cancer, for example, hypermethylation of $\mathrm{MLH} 1$ promoter is responsible for the development of $>50 \%$ of cases, whereas mutations in $M L H 1$ and $M S H 2$ account for $~ 15 \%$ of cases $(102,103)$.

Small insertions/deletions may create frame-shift mutations within repetitive tracts present in the coding region of essential tumor-suppressor or tumor-associated genes, resulting in an inactive protein and contributing to tumorigenesis in cancers with MSI-H (104). Using a large-scale genomic screen of coding region microsatellites, Mori et al (105) identified nine loci that were mutated in $>20 \%$ of tumors, namely: Transforming growth factor- $\beta$ receptor (TGFBR2) (79.1\%), BCL2 associated $\mathrm{X}$ apoptosis regulator $(B A X)(37.5 \%)$, human mutS homolog 3 (26.2\%), activin A receptor, type II (58.1\%), SEC63 homolog protein translocation regulator (48.8\%), absent in melanoma $2(47.6 \%)$, NADH-ubiquinone oxidoreductase $(27.9 \%)$, cordon-bleu WH2 repeat protein like 1 (23.8\%) and proliferation-associated $2 \mathrm{G} 4 /$ ErbB3-binding protein 1 (20.9\%). $T G F B R 2$, encoding a kinase receptor involved in transduction of the $T G F B 1 / 2 / 3$ signal from the cell surface to the cytoplasm to inhibit cellular proliferation, is the most commonly affected gene. Particularly, instability in the poly-adenine tract of this gene has been detected in $\sim 85 \%$ of MSI-H colorectal tumors, rendering an inactive receptor and thus eliminating the growth-suppressive effects of TGFB1 (106). Another commonly mutated gene in CRC is $B A X$, a pro-apoptotic gene belonging to the $B C L 2$ family. Frame-shift mutations within the poly-guanine sequence have been detected in $50 \%$ of MSI-H colorectal tumors, causing silencing of this gene and suppressing apoptosis (107). These alterations in the gene functions represent a possible mechanism for MSI carcinogenesis. 


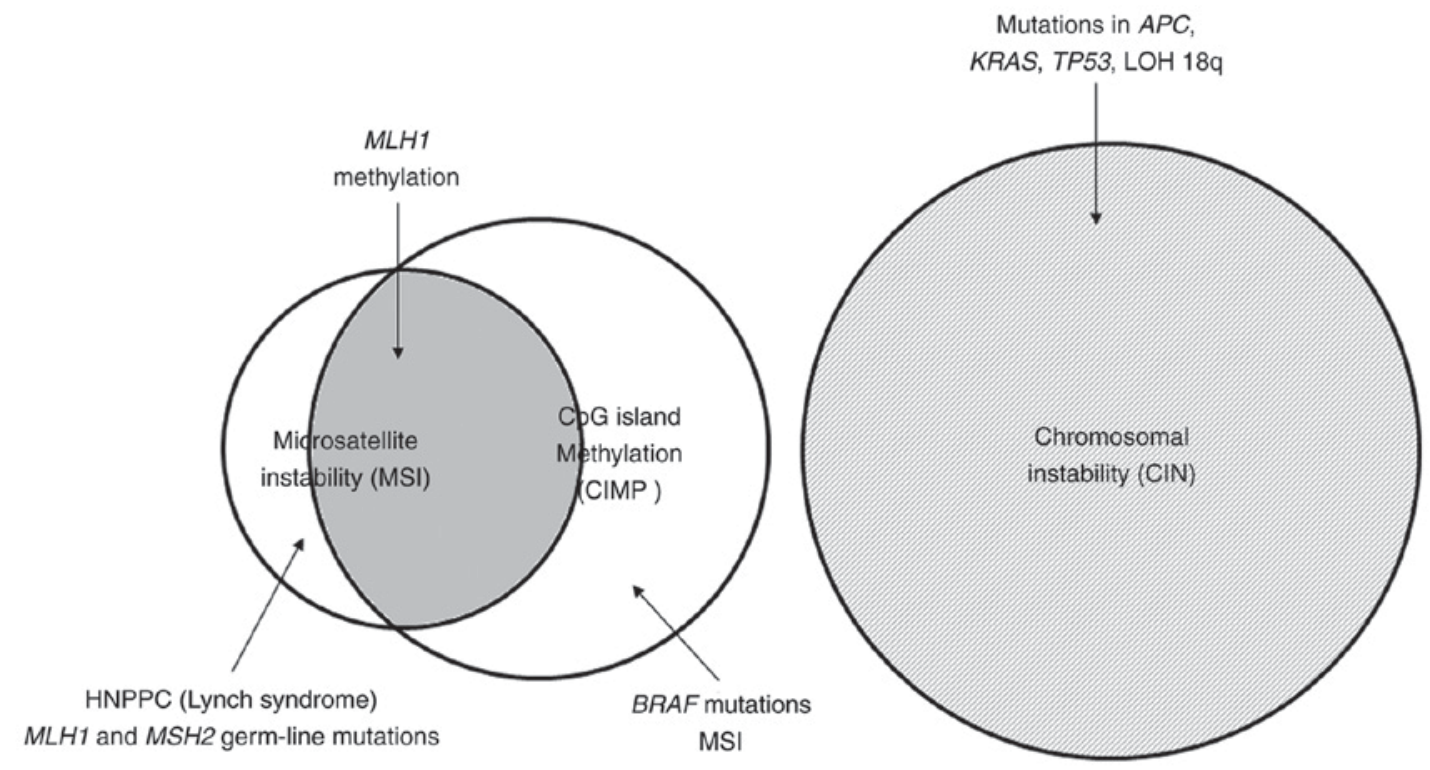

Figure 2. Overview of the genetic and epigenetic instability pathways that drive colorectal cancer onset and development. CIN, Chromosomal instability; MSI, microsatellite instability; CIMP, $\mathrm{CpG}$ island methylator phenotype; $A P C$, adenomatous polyposis; $K R A S$, KRAS proto-oncogene GTPase; $B R A F$, B-Raf proto-oncogene serine/threonine kinase; TP53, tumor protein 53; LOH, loss of heterozygosity; HNPPC, hereditary non-polyposis colorectal cancer; MLH1, mutL homolog 1; MSH2, mutS homolog 2.

CIMP or aberrant DNA methylation. Transcription inactivation by DNA hypermethylation at promoter $\mathrm{CpG}$ islands of tumor-suppressor genes, causing gene silencing, is now recognized as an important mechanism in human carcinogenesis (108-111). The CpG island methylator phenotype has been identified in 30-35\% colorectal adenoma cases, and is considered as an early event and a characteristic for the serrated pathway of colorectal tumorigenesis $(108,112,113)$. However, the quantitative DNA methylation study performed by Ogino et al (114) reported that CIMP accounts for $17 \%$ of CRC, which is less frequent compared with previously reported and that clinical features of CIMP are similar to those of MSI-associated CRC (114). Notably, sporadic MSI colorectal tumors are almost exclusively associated with CIMP-associated methylation of $M L H 1$ leading to inactivation of this gene $(107,115)$. In contrast, the familial MSI cases (Lynch syndrome) are generally caused by germline mutations in the MMR genes, primarily including $M L H 1$ and $M S H 2$, and accounts for $<5 \%$ of all CRC cases (Fig. 2) (107,116).

The CIMP status of CRC is currently assessed by a panel of methylation markers categorizing CRC as exhibiting or not exhibiting DNA methylation on the basis of certain thresholds $(114,115,117,118)$. CIMP ${ }^{+}$colorectal tumors appear to have a distinct profile, including associations with the proximal colon, poor differentiation, MSI status, $B R A F$ mutation and wild-type KRAS (113-115,119-121). Particularly, the frequency of $B R A F$ mutations in $\mathrm{CIMP}^{+}$tumors is significantly higher compared with their CIMP- counterparts $(114,115)$. Shen et al (122) analyzed the genetic and epigenetic alterations in 97 primary CRC samples, and demonstrated that CIMP-high tumors are associated with MSI status (80\%) and BRAF mutation (53\%); CIMP-low tumors are associated with KRAS mutations (92\%); and CIMP- tumors typically have a high rate of p53 mutations (71\%) (122). Furthermore, CIMP status has also been indicated to be negatively associated with $18 \mathrm{q} \mathrm{LOH}$ status in colorectal tumors (117). Particularly, CIMP-0 was associated with 18q LOH-positive tumors and vice versa (117).

\section{Clinical implication of the molecular genetics of CRC}

The prognosis and therapeutic options for patients with CRC are associated with the stage at which they are first diagnosed. While early stage CRC is often cured with surgery alone, more advanced or metastatic CRC generally require additional adjuvant chemotherapy or targeted therapy, either alone or as a combined treatment. Early detection of CRC thus becomes important to reduce the incidence and mortality of the disease. Furthermore, due to their heterogeneity, the benefits from adjuvant chemotherapy for stage II and III CRC patients may vary largely. Thus, identifying molecular prognostic markers that are capable of recognizing patients with CRC more likely to recur or benefit from adjuvant chemotherapy may improve the prognosis and assist in the selection of appropriate therapy, and subsequently the general outcomes.

It is now widely known that certain alterations at the molecular level favor CRC onset, progression and metastasis (60). Several known mutations are considered to be associated with a poorer patient outcome and/or failure of response to a certain therapy (18). Patients with inactive TP53 mutations, for example, are at an increased risk of mortality compared with their counterparts, but this mutation does not appear to affect the outcome of chemotherapy (123). However, the presence of somatic KRAS mutations has been considered as a predictor of resistance to anti-EGFR therapy $(83-86,124)$. Thus, KRAS mutation status is currently used in clinical settings to predict the therapeutic effectiveness of CRC prior to chemotherapy to avoid any undesired effects and medical costs (125). APC is another commonly affected gene whose mutations generally appear in the early stage of CRC development $(55,60)$. Notably, the risk of $\mathrm{CRC}$ for a patient with FAP, which begins with a 
germline mutation in one allele of the $A P C$ gene is $\sim 100 \%$ by the age of 40 years $(6,7)$. Therefore, $A P C$ mutations are being considered as good diagnostic markers for identifying individuals at risk of CRC.

The majority ( 75\%) of CRC with MSI are sporadic cases caused by the loss of DNA MMR activity due to methylation of the promoter of the $M L H 1$ gene, while the other $25 \%$ of cases are classified as Lynch syndrome caused by germline mutations in the MMR genes (Fig. 2). Generally, MSI is detected earlier in life in patients with Lynch syndrome $(<50$ years old) as compared with the sporadic cases ( $>65$ years old) (126). Particularly, CRC with MSI are more likely to occur in the proximal colon (126). Evidence has suggested that MSI is a favorable prognostic biomarker for CRC (127-129). However, its predictive role for the response to chemotherapeutic agents, including 5-fluorouracil (5-FU) is conflicting. Several studies demonstrated a lack of benefit of 5-FU-based adjuvant chemotherapy in patients with CRC with MSI tumors (130-133), while others reported the beneficial effects $(127,134)$. Des Guetz et al $(135)$ performed a meta-analysis involving 3,690 patients from seven different studies, and reported that chemotherapy had a beneficial effect among MSS, but not MSI-H patients (135). In addition, the more improved survival rate of MSI-H patients was due to a better prognosis rather than the benefit of chemotherapy (135). These findings suggested that MSI may be considered as a predictive marker of chemoresistance and that patients with CRC with MSI may be spared from adjuvant treatment. The MSI status among patients with CRC, thus, is highly valuable in prognosis and therapy of CRC, and should be thoroughly evaluated by performing polymerase chain reaction analysis using the Bethesda panel and/or immunohistochemistry staining for DNA MMR proteins, including MLH1 and MSH2, in order to contribute to treatment decision-making regarding chemotherapy administration.

Several groups have used gene expression profiling to classify CRC, and to identify genes associated with prognosis and prediction of disease outcome. De Sousa et al (136) used an unsupervised classification strategy involving $>1,100$ individuals with colon cancer and defined three main colon cancer subtypes. Two subtypes are associated with two well-characterized subsets of colon cancer, namely the CIN and the MSI group. The third subtype was largely MSS and overlaps partly with the CIMP group, and is associated with poor prognosis and resistance to anti-EGFR therapy (136). Using a similar approach,Sadanandam et al (137) defined six clinically relevant CRC subtypes by associating their gene expression profiles with corresponding clinical response to cetuximab. Patients with stem-like subtype and inflammatory subtype tumors, with poor and intermediate disease-free survival, exhibited an improved response to the combination chemotherapy regimen FOLFIRI (5-FU with irinotecan) in adjuvant or metastatic settings, whereas transit-amplifying- and goblet-like-subtype tumors, with markedly better prognosis, did not appear to benefit from these treatments. However, cetuximab-sensitive transit-amplifying and cetuximab-resistant transit-amplifying subtypes may be efficiently treated with cetuximab or a cMET inhibitor, respectively, in the metastatic setting (137). Although there are significant associations between MSI status and specific subtypes, the transcriptional signatures-based subtypes allow better refinement and provide insights for the development of subtype-specific therapies, which, in turn, may contribute to the more effective management of this disease.

\section{Conclusion and future perspectives}

Despite the great advancement in CRC research, the role of the molecular characterization in diagnostic tests and therapeutic decisions remains limited due to the fact that the function of the majority of mutations remains unclear and rarely provides any valuable diagnostic information. Further research is required to develop more easily applicable molecular tests for early detection of CRC, which is essential to improving the prognosis and treatment efficiency. Furthermore, it is essential to identify novel therapeutic targets as the majority of CRC cases are insensitive to EGFR inhibitor therapy.

Recent studies have provided a better understanding of CRC and assist in the development of novel treatment regimens. Particularly, the implementation of targeted next-generation sequencing (NGS) in clinical settings allows a reliable identification of the most common mutations, and is able to guide therapeutic decisions for patients with CRC based on personalized medicine (138). NGS is currently the most important technology for early diagnosis and prognosis, as well as identification of novel predictive biomarkers for available treatments with targeted therapy and immunotherapy for patients with CRC (138). Specifically, the combination of CRISPR/Cas9 technology and immunotherapy would significantly improve patient care by reducing side effects $(139,140)$.

\section{Acknowledgements}

The authors would like to thank Dr. Adam F. Johnson (Center for Molecular Biology, Institute of Research and Development, Duy Tan University, Danang, Vietnam) for the critical reading of the manuscript.

\section{Funding}

This study was supported by the National Foundation for Science and Technology Development (NAFOSTED; grant no. 106-YS.01-2015.12).

\section{Availability of data and materials}

Not applicable.

\section{Authors' contributions}

HTN conceptualized the article, critically discussed the findings and co-wrote the article. HQD co-wrote the article. Both authors revised the article and approved the final version.

\section{Ethics approval and consent to participate}

Not applicable. 


\section{Consent for publication}

Not applicable.

\section{Competing interests}

The authors declare that they have no competing interests.

\section{References}

1. Torre LA, Siegel RL, Ward EM and Jemal A: Global cancer incidence and mortality rates and trends-an update. Cancer Epidemiol Biomarkers Prev 25: 16-27, 2016.

2. Ferlay J, Soerjomataram I, Dikshit R, Eser S, Mathers C, Rebelo M, Parkin DM, Forman D and Bray F: Cancer incidence and mortality worldwide: Sources, methods and major patterns in GLOBOCAN 2012. Int J Cancer 136: E359-E386, 2015.

3. Burt R: Inheritance of colorectal cancer. Drug Discov Today Dis Mech 4: 293-300, 2007.

4. Hendon SE and DiPalma JA: U.S. practices for colon cancer screening. Keio J Med 54: 179-183, 2005.

5. Lengauer C, Kinzler KW and Vogelstein B: Genetic instabilities in human cancers. Nature 396: 643-649, 1998.

6. Markowitz SD and Bertagnolli MM: Molecular origins of cancer: Molecular basis of colorectal cancer. N Engl J Med 361: 2449-2460, 2009.

7. Tsang AH, Cheng KH, Wong AS, Ng SS, Ma BB, Chan CM Tsui NB, Chan LW, Yung BY and Wong SC: Current and future molecular diagnostics in colorectal cancer and colorectal adenoma. World J Gastroenterol 20: 3847-3857, 2014.

8. Grady WM and Pritchard CC: Molecular alterations and biomarkers in colorectal cancer. Toxicol Pathol 42: 124-139, 2014.

9. Fransén K, Klintenäs M, Österström A, Dimberg J, Monstein HJ and Söderkvist P: Mutation analysis of the BRAF, ARAF and RAF-1 genes in human colorectal adenocarcinomas. Carcinogenesis 25: 527-533, 2004.

10. Pino MS and Chung DC: The chromosomal instability pathway in colon cancer. Gastroenterology 138: 2059-2072, 2010.

11. Lynch HT and de la Chapelle A: Hereditary colorectal cancer. N Engl J Med 348: 919-932, 2003.

12. Fearon ER and Vogelstein B: A genetic model for colorectal tumorigenesis. Cell 61: 759-767, 1990.

13. Hanahan D and Weinberg RA: The hallmarks of cancer. Cell 100 57-70, 2000

14. Grady WM: Epigenetic events in the colorectum and in colon cancer. Biochem Soc Trans 33: 684-688, 2005.

15. Kinzler KW and Vogelstein B: Lessons from hereditary colorectal cancer. Cell 87: 159-170, 1996.

16. Tejpar S and Van Cutsem E: Molecular and genetic defects in colorectal tumorigenesis. Best Pract Res Clin Gastroenterol 16: $171-185,2002$

17. O'Connell JB, Maggard MA and Ko CY: Colon cancer survival rates with the new American Joint Committee on Cancer sixth edition staging. J Natl Cancer Inst 96: 1420-1425, 2004.

18. Reimers MS, Zeestraten EC, Kuppen PJ, Liefers GJ and van de Velde CJ: Biomarkers in precision therapy in colorecta cancer. Gastroenterol Rep (Oxf) 1: 166-183, 2013.

19. Nachman MW and Crowell SL: Estimate of the mutation rate per nucleotide in humans. Genetics 156: 297-304, 2000

20. Roach JC, Glusman G, Smit AF, Huff CD, Hubley R, Shannon PT, Rowen L, Pant KP, Goodman N, Bamshad M, et al: Analysis of genetic inheritance in a family quartet by whole-genome sequencing. Science 328: 636-639, 2010.

21. Loeb LA, Loeb KR and Anderson JP: Multiple mutations and cancer. Proc Natl Acad Sci USA 100: 776-781, 2003.

22. Markowitz S, Wang J, Myeroff L, Parsons R, Sun L, Lutterbaugh J, Fan RS, Zborowska E, Kinzler KW, Vogelstein B, et al: Inactivation of the type II TGF-beta receptor in colon cancer cells with microsatellite instability. Science 268: 1336-1338, 1995.

23. Samuels Y, Wang Z, Bardelli A, Silliman N, Ptak J, Szabo S, Yan H, Gazdar A, Powell SM, Riqqins GJ, et al: High frequency of mutations of the PIK3CA gene in human cancers. Science 304 $554,2004$.

24. Baker SJ, Fearon ER, Nigro JM, Hamilton SR, Preisinger AC, Jessup JM, vanTuinen P, Ledbetter DH, Barker DF, Nakamura Y, et al: Chromosome 17 deletions and p53 gene mutations in colorectal carcinomas. Science 244: 217-221, 1989.
25. Thiagalingam S, Lengauer C, Leach FS, Schutte M, Hahn SA, Overhauser J, Willson JK, Markowitz S, Hamilton SR, Kern SE, et al: Evaluation of candidate tumour suppressor genes on chromosome 18 in colorectal cancers. Nat Genet 13: 343-346, 1996.

26. Diep CB, Kleivi K, Ribeiro FR, Teixeira MR, Lindgjærde OC and Lothe RA: The order of genetic events associated with colorectal cancer progression inferred from meta-analysis of copy number changes. Genes Chromosomes Cancer 45: 31-41, 2006.

27. Jasmine F, Rahaman R, Dodsworth C, Roy S, Paul R, Raza M, Paul-Brutus R, Kamal M, Ahsan H and Kibriya MG: A genome-wide study of cytogenetic changes in colorectal cancer using SNP microarrays: Opportunities for future personalized treatment. PLoS One 7: e31968, 2012.

28. Baudis M: Genomic imbalances in 5918 malignant epithelial tumors: An explorative meta-analysis of chromosomal $\mathrm{CGH}$ data. BMC Cancer 7: 226, 2007.

29. Jones AM, Douglas EJ, Halford SE, Fiegler H, Gorman PA, Roylance RR, Carter NP and Tomlinson IP: Array-CGH analysis of microsatellite-stable, near-diploid bowel cancers and comparison with other types of colorectal carcinoma. Oncogene 24: $118-129,2005$.

30. Zarzour P, Boelen L, Luciani F, Beck D, Sakthianandeswaren A, Mouradov D, Sieber OM, Hawkins NJ, Hesson LB, Ward RL and Wong JW: Single nucleotide polymorphism array profiling identifies distinct chromosomal aberration patterns across colorectal adenomas and carcinomas. Genes Chromosomes Cancer 54: 303-314, 2015.

31. Cancer Genome Atlas Network: Comprehensive molecular characterization of human colon and rectal cancer. Nature 487: $330-337,2012$.

32. Foulds L: The natural history of cancer. J Chronic Dis 8: 2-37, 1958.

33. Nowell PC: The clonal evolution of tumor cell populations. Science 194: 23-28, 1976

34. Nguyen HT, Geens M and Spits C: Genetic and epigenetic instability in human pluripotent stem cells. Hum Reprod Update 19: 187-205, 2013.

35. Lund RJ, Närvä E and Lahesmaa R: Genetic and epigenetic stability of human pluripotent stem cells. Nat Rev Genet 13 732-744, 2012.

36. International Stem Cell Initiative; Amps K, Andrews PW, Anyfantis G, Armstrong L, Avery S, Baharvand H, Baker J, Barker D, Munoz MB, et al: Screening ethnically diverse human embryonic stem cells identifies a chromosome 20 minimal amplicon conferring growth advantage. Nat Biotechnol 29: 1132-1144, 2011

37. Nguyen HT, Geens M, Mertzanidou A, Jacobs K, Heirman C, Breckpot K and Spits C: Gain of 20q11.21 in human embryonic stem cells improves cell survival by increased expression of Bcl-xL. Mol Hum Reprod 20: 168-177, 2014.

38. Avery S, Hirst AJ, Baker D, Lim CY, Alagaratnam S, Skotheim RI, Lothe RA, Pera MF, Colman A, Robson P, et al: BCL-XL Mediates the strong selective advantage of a 20q11.21 amplification commonly found in human embryonic stem cell cultures. Stem Cell Reports 1: 379-386, 2013.

39. Beroukhim R, Mermel CH, Porter D, Wei G, Raychaudhuri S, Donovan J, Barretina J, Boehm JS, Dobson J, Urashima M, et al: The landscape of somatic copy-number alteration across human cancers. Nature 463: 899-905, 2010.

40. Vogelstein B, Fearon ER, Hamilton SR, Kern SE, Preisinger AC Leppert M, Nakamura Y, White R, Smits AM and Bos JL: Genetic alterations during colorectal-tumor development. N Engl J Med 319: 525-532, 1988.

41. Ogino S, Nosho K, Irahara N, Shima K, Baba Y, Kirkner GJ, Meyerhardt JA and Fuchs CS: Prognostic significance and molecular associations of 18q loss of heterozygosity: A cohort study of microsatellite stable colorectal cancers. J Clin Oncol 27: 4591-4598, 2009.

42. Sheffer M, Bacolod MD, Zuk O, Giardina SF, Pincas H, Barany F, Paty PB, Gerald WL, Notterman DA and Domany E: Association of survival and disease progression with chromosomal instability: A genomic exploration of colorectal cancer. Proc Nat Acad Sci USA 106: 7131-7136, 2009.

43. Jen J, Kim H, Piantadosi S, Liu ZF, Levitt RC, Sistonen P, Kinzler KW, Vogelstein B and Hamilton SR: Allelic loss of chromosome $18 \mathrm{q}$ and prognosis in colorectal cancer. N Engl J Med 331: 213-221, 1994. 
44. Zauber P, Sabbath-solitare M, Marotta SP and Bishop T: Loss of heterozygosity for chromosome $18 \mathrm{q}$ and microsatellite instability are highly consistent across the region of the DCC and SMAD4 genes in colorectal carcinomas and adenomas. J Appl Res 8: 14-23, 2008.

45. Fearon ER, Cho KR, Nigro JM, Kern SE, Simons JW, Ruppert JM, Hamilton SR, Preisinger AC, Thomas G, Kinzler KW, et al: Identification of a chromosome $18 \mathrm{q}$ gene that is altered in colorectal cancers. Science 247: 49-56, 1990.

46. Mehlen P and Fearon ER: Role of the dependence receptor DCC in colorectal cancer pathogenesis. J Clin Oncol 22: 3420-3428, 2004.

47. Alazzouzi H, Alhopuro P, Salovaara R, Sammalkorpi H, Järvinen H, Mecklin JP, Hemminki A, Schwartz S Jr, Aaltonen LA and Arango D: SMAD4 as a prognostic marker in colorectal cancer. Clin Cancer Res 11: 2606-2611, 2005.

48. Grady WM: Genomic instability and colon cancer. Cancer Metastasis Rev 23: 11-27, 2004.

49. Shi Y, Hata A, Lo RS, Massagué J and Pavletich NP: A structural basis for mutational inactivation of the tumour suppressor Smad4. Nature 388: 87-93, 1997.

50. Hahn SA, Schutte M, Hoque AT, Moskaluk CA, da Costa LT, Rozenblum E, Weinstein CL, Fischer A, Yeo CJ, Hurban RH and Kern SE: DPC4, a candidate tumor suppressor gene at human chromosome 18q21.1. Science 271: 350-353, 1996.

51. Takagi Y, Kohmura H, Futamura M, Kida H, Tanemura H, Shimokawa K and Saji S: Somatic alterations of the DPC4 gene in human colorectal cancers in vivo. Gastroenterology 111: 1369-1372, 1996.

52. Takagi Y, Koumura H, Futamura M, Aoki S, Ymaguchi K, Kida H, Tanemura H, Shimokawa K and Saji S: Somatic alterations of the SMAD-2 gene in human colorectal cancers. Br J Cancer 78: 1152-1155, 1998.

53. Fleming NI, Jorissen RN, Mouradov D, Christie M, Sakthianandeswaren A, Palmieri M, Day F, Li S, Tsui C, Lipton L, et al: SMAD2, SMAD3 and SMAD4 mutations in colorectal cancer. Cancer Res 73: 725-735, 2013.

54. Takebayashi S, Ogawa T, Jung KY, Muallem A, Mineta H, Fisher SG, Grenman R and Carey TE: Identification of new minimally lost regions on $18 \mathrm{q}$ in head and neck squamous cell carcinoma. Cancer Res 60: 3397-3403, 2000.

55. Powell SM, Zilz N, Beazer-Barclay Y, Bryan TM, Hamilton SR Thibodeau SN, Vogelstein B and Kinzler KW: APC mutations occur early during colorectal tumorigenesis. Nature 359 : 235-237, 1992.

56. MacDonald BT, Tamai $\mathrm{K}$ and $\mathrm{He} \mathrm{X}$ : Wnt/beta-catenin signaling: Components, mechanisms, and diseases. Dev Cell 17: 9-26, 2009

57. Stanczak A, Stec R, Bodnar L, Olszewski W, Cichowicz M, Kozlowski W, Szcylik C, Pietrucha T, Wieczorek M and Lamparska-Pzybysz M: Prognostic significance of Wnt-1, $\beta$-catenin and E-cadherin expression in advanced colorectal carcinoma. Pathol Oncol Res 17: 955-963, 2011.

58. Morin PJ, Sparks AB, Korinek V, Barker N, Clevers H, Vogelstein B and Kinzler KW: Activation of $\beta$-catenin-Tc signaling in colon cancer by mutations in beta-catenin or APC. Science 275: 1787-1790, 1997.

59. Liu W, Dong X, Mai M, Seelan RS, Taniguchi K, Krishnadath KK, Halling KC, Cunningham JM, Boardman LA, Qian C, et al: Mutations in AXIN2 cause colorectal cancer with defective mismatch repair. Nat Genet 26: 146-147, 2000.

60. Coppedè F, Lopomo A, Spisni R and Migliore L: Genetic and epigenetic biomarkers for diagnosis, prognosis and treatment of colorectal cancer. World J Gastroenterol 20: 943-956, 2014.

61. Kapitanović S, Cacev T, Radosević S, Spaventi S, Spaventi R and Pavelić K: APC gene loss of heterozygosity, mutations, E1317Q, and $\mathrm{I} 1307 \mathrm{~K}$ germ-line variants in sporadic colon cancer in Croatia. Exp Mol Pathol 77: 193-200, 2004.

62. Esteller M: Epigenetic lesions causing genetic lesions in human cancer: Promoter hypermethylation of DNA repair genes. Eur J Cancer 36: 2294-2300, 2000.

63. Levine AJ: P53, the cellular gatekeeper for growth and division. Cell 88: 323-331, 1997.

64. el-Deiry WS: Regulation of p53 downstream genes. Semin Cancer Biol 8: 345-357, 1998.

65. Li XL, Zhou J, Chen ZR and Chng WJ: P53 mutations in colorectal cancer-molecular pathogenesis and pharmacological reactivation. World J Gastroenterol 21: 84-93, 2015.

66. Leslie A, Carey FA, Pratt NR and Steele RJ: The colorectal adenoma-carcinoma sequence. Br J Surg 89: 845-860, 2002.
67. Takayama T, Miyanishi K, Hayashi T, Sato Y and Niitsu Y: Colorectal cancer: Genetics of development and metastasis. J Gastroenterol 41: 185-192, 2006

68. Sigal A and Rotter V: Oncogenic mutations of the p53 tumor suppressor: The demons of the guardian of the genome. Cancer Res 60: 6788-6793, 2000.

69. Liu Y and Bodmer WF: Analysis of P53 mutations and their expression in 56 colorectal cancer cell lines. Proc Natl Acad Sci USA 103: 976-981, 2006.

70. Béroud C and Soussi T: The UMD-p53 database: New mutations and analysis tools. Hum Mutat 21: 176-181, 2003.

71. Vigil D, Cherfils J, Rossman KL and Der CJ: Ras superfamily GEFs and GAPs: Validated and tractable targets for cancer therapy? Nat Rev Cancer 10: 842-857, 2010.

72. Schubbert S, Shannon K and Bollag G: Hyperactive Ras in developmental disorders and cancer. Nat Rev Cancer 7: 295-308, 2007.

73. Adjei AA: Ras signaling pathway proteins as therapeutic targets. Curr Pharm Des 7: 1581-1594, 2001.

74. Downward J: Targeting RAS signalling pathways in cancer therapy. Nat Rev Cancer 3: 11-22, 2003

75. Forbes SA, Bindal N, Bamford S, Cole C, Kok CY, Beare D, Jia M, Shepherd R, Leung K, Menzies A, et al: COSMIC: Mining complete cancer genomes in the catalogue of somatic mutations in cancer. Nucleic Acids Res 39 (Database issue): D945-D950, 2011.

76. Tan $\mathrm{C}$ and Du X: KRAS mutation testing in metastatic colorectal cancer. World J Gastroenterol 18: 5171-5180, 2012.

77. Conlin A, Smith G, Carey FA, Wolf CR and Steele RJ: The prognostic significance of K-ras, p53, and APC mutations in colorectal carcinoma. Gut 54: 1283-1286, 2005.

78. Phipps AI, Buchanan DD, Makar KW, Win AK, Baron JA, Lindor NM, Potter JD and Newcomb PA: KRAS-mutation status in relation to colorectal cancer survival: The joint impact of correlated tumour markers. Br J Cancer 108: 1757-1764, 2013.

79. Cejas P, López-Gómez M, Aguayo C, Madero R, de Castro Carpeño J, Belda-Iniesta C, Barriuso J, Moreno García V, Larrauri J, López R, et al: KRAS mutations in primary colorectal cancer tumors and related metastases: A potential role in prediction of lung metastasis. PLoS One 4: e8199, 2009.

80. Kim HS, Heo JS, Lee J, Lee JY, Lee MY, Lim SH, Lee WY, Kim SH, Park YA, Cho YB, et al: The impact of KRAS mutations on prognosis in surgically resected colorectal cancer patients with liver and lung metastases: A retrospective analysis. BMC Cancer 16: 120, 2016.

81. Nash GM, Gimbel M, Shia J, Nathanson DR, Ndubuisi MI, Zeng ZS, Kemeny N and Paty PB: KRAS mutation correlates with accelerated metastatic progression in patients with colorectal liver metastases. Ann Surg Oncol 17: 572-578, 2010.

82. Inoue Y, Saigusa S, Iwata T, Okugawa Y, Toiyama Y, Tanaka K, Uchida K, Mohri Y and Kusunoki M: The prognostic value of KRAS mutations in patients with colorectal cancer. Oncol Rep 28: 1579-1584, 2012.

83. Amado RG, Wolf M, Peeters M, Van Cutsem E, Siena S, Freeman DJ, Juan T, Sikorski R, Suqqs S, Radinsky R, et al: Wild-type KRAS is required for panitumumab efficacy in patients with metastatic colorectal cancer. J Clin Oncol 26: 1626-1634, 2008

84. Lièvre A, Bachet JB, Boige V, Cayre A, Le Corre D, Buc E, Ychou M, Bouché $\mathrm{O}$, Landi $\mathrm{B}$, Louvet $\mathrm{C}$, et al: KRAS mutations as an independent prognostic factor in patients with advanced colorectal cancer treated with cetuximab. J Clin Oncol 26: 374-379, 2008.

85. Karapetis CS, Khambata-Ford S, Jonker DJ, O'Callaghan CJ, Tu D, Tebbutt NC, Simes RJ, Chalchal H, Shapiro JD, Robitalle $\mathrm{S}$, et al: K-ras mutations and benefit from cetuximab in advanced colorectal cancer. N Engl J Med 359: 1757-1765, 2008.

86. Siena S, Sartore-Bianchi A, Di Nicolantonio F, Balfour J and Bardelli A: Biomarkers predicting clinical outcome of epidermal growth factor receptor-targeted therapy in metastatic colorectal cancer. J Natl Cancer Inst 101: 1308-1324, 2009.

87. Bos JL, Fearon ER, Hamilton SR, Verlaan-de Vries M, van Boom JH, van der Eb AJ and Vogelstein B: Prevalence of ras gene mutations in human colorectal cancers. Nature 327: 293-297, 1987.

88. Forrester K, Almoguera C, Han K, Grizzle WE and Perucho M: Detection of high incidence of K-ras oncogenes during human colon tumorigenesis. Nature 327: 298-303, 1987.

89. Fernández-Medarde A and Santos E: Ras in cancer and developmental diseases. Genes Cancer 2: 344-358, 2011. 
90. Neumann J, Zeindl-Eberhart E, Kirchner T and Jung A: Frequency and type of KRAS mutations in routine diagnostic analysis of metastatic colorectal cancer. Pathol Res Pract 205: 858-862, 2009.

91. Irahara N, Baba Y, Nosho K, Shima K, Yan L, Dias-Santagata D, Iafrate AJ, Fuchs CS, Haigis KM and Ogino S: NRAS mutations are rare in colorectal cancer. Diagn Mol Pathol 19: 157-163, 2010.

92. Vaughn CP, ZoBell SD, Furtado LV, Baker CL and Samowitz WS: Frequency of KRAS, BRAF, and NRAS mutations in colorectal cancer. Genes Chromosomes Cancer 50: 307-312, 2011

93.Kosmidou V, Oikonomou E, Vlassi M, Avlonitis S, Katseli A, Tsipras I, Mourtzoukou D, Kontogeorgos G, Zografos $G$ and Pintzas A: Tumor heterogeneity revealed by KRAS, BRAF, and PIK3CA pyrosequencing: KRAS and PIK3CA intratumor mutation profile differences and their therapeutic implications. Hum Mutat 35: 329-340, 2014.

94. Abdel-Rahman WM and Peltomäki P: Molecular basis and diagnostics of hereditary colorectal cancers. Ann Med 36: 379-388, 2014

95. Thibodeau SN, Bren G and Schaid D: Microsatellite instability in cancer of the proximal colon. Science 260 816-819, 1993

96. Boland CR and Goel A: Somatic evolution of cancer cells. Semin Cancer Biol 15: 436-450, 2005.

97. Boland CR, Thibodeau SN, Hamilton SR, Sidransky D, Eshleman JR, Burt RW, Meltzer SJ, Rodriguez-Bigas MA, Fodde R, Ranzani GN and Srivastava S: A national cancer institute workshop on microsatellite instability for cancer detection and familial predisposition: Development of international criteria for the determination of microsatellite instability in colorectal cancer. Cancer Res 58: 5248-5257, 1998.

98. Findeisen P, Kloor M, Merx S, Sutter C, Woerner SM, Dostmann N, Benner A, Dondog B, Pawlita M, Dippold W, et al T25 repeat in the 3' untranslated region of the CASP2 gene: A sensitive and specific marker for microsatellite instability in colorectal cancer. Cancer Res 65: 8072-8078, 2005

99. Aaltonen LA, Peltomäki P, Leach FS, Sistonen P, Pylkkänen L, Mecklin JP, Järvinen H, Powell SM, Jen J, Hamilton SR, et al Clues to the pathogenesis of familial colorectal cancer. Science 260: 812-816, 1993

100. Jiricny J: The multifaceted mismatch-repair system. Nat Rev Mol Cell Biol 7: 335-346, 2006.

101. Pal T, Permuth-Wey J and Sellers TA: A review of the clinical relevance of mismatch-repair deficiency in ovarian cancer. Cancer 113: 733-742, 2008.

102. Grady WM and Carethers JM: Genomic and epigenetic instability in colorectal cancer pathogenesis. Gastroenterology 135 1079-1099, 2008

103. Hudler P: Genetic aspects of gastric cancer instability. Scientific World Journal 2012: 761909, 2012.

104. Perucho M: Cancer of the microsatellite mutator phenotype. Biol Chem 377: 675-684, 1996.

105. Mori Y, Yin J, Rashid A, Leggett BA, Young J, Simms L, Kuehl PM, Langenberg P, Meltzer SJ and Stine OC: Instabilotyping: Comprehensive identification of frameshift mutations caused by coding region microsatellite instability. Cancer Res 61: 6046-6049, 2001.

106. Parsons R, Myeroff LL, Liu B, Wilison JK V, Markowitz SD, Kinzler KW and Vogelstein B: Microsatellite instability and mutations of the transforming growth factor $\beta$ type II receptor gene in colorectal cancer. Cancer Res 55: 5548-5550, 1995.

107. Boland CR and Goel A: Microsatellite instability in colorectal cancer. Gastroenterology 138: 2073-2087.e3, 2010.

108. Toyota M, Ahuja N, Ohe-Toyota M, Herman JG, Baylin SB and Issa JP: $\mathrm{CpG}$ island methylator phenotype in colorectal cancer. Proc Natl Acad Sci USA 96: 8681-8686, 1999.

109. Lao VV and Grady WM: Epigenetics and colorectal cancer. Nat Rev Gastroenterol Hepatol 8: 686-700, 2011.

110. Jones PA and Laird PW: Cancer epigenetics comes of age. Nat Genet 21: 163-167, 1999 .

111. Laird PW: Cancer epigenetics. Hum Mol Genet 14: R65-R76, 2005.

112. Jass JR: Serrated adenoma of the colorectum and the DNA-methylator phenotype. Nat Clin Pract Oncol 2: 398-405, 2005 .
113. Samowitz WS, Albertsen H, Herrick J, Levin TR, Sweeney C, Murtaugh MA, Wolff RK and Slattery ML: Evaluation of a large, population-based sample supports a $\mathrm{CpG}$ island methylator phenotype in colon cancer. Gastroenterology 129: 837-845, 2005 .

114. Ogino S, Cantor M, Kawasaki T, Brahmandam M, Kirkner GJ, Weisenberger DJ, Campan M, Laird PW, Loda M and Fuchs CS: $\mathrm{CpG}$ island methylator phenotype (CIMP) of colorectal cancer is best characterised by quantitative DNA methylation analysis and prospective cohort studies. Gut 55: 1000-1006, 2006.

115. Weisenberger DJ, Siegmund KD, Campan M, Young J, Long TI, Faasse MA, Kang GH, Widschwendter M, Weener D, Buchanan D, et al: CpG island methylator phenotype underlies sporadic microsatellite instability and is tightly associated with BRAF mutation in colorectal cancer. Nat Genet 38: 787-793, 2006.

116. Worthley DL and Leggett BA: Colorectal cancer: Molecular features and clinical opportunities. Clin Biochem Rev 31: 31-38, 2010.

117. Ogino S, Kawasaki T, Kirkner GJ, Ohnishi M and Fuchs CS: 18q loss of heterozygosity in microsatellite stable colorectal cancer is correlated with $\mathrm{CpG}$ island methylator phenotype-negative (CIMP-0) and inversely with CIMP-low and CIMP-high. BMC Cancer 7: 72, 2007.

118. Ogino S, Kawasaki T, Kirkner GJ, Kraft P, Loda M and Fuchs CS: Evaluation of markers for $\mathrm{CpG}$ island methylator phenotype (CIMP) in colorectal cancer by a large population-based sample. J Mol Diagn 9: 305-314, 2007

119. Toyota M, Ohe-Toyota M, Ahuja N and Issa JP: Distinct genetic profiles in colorectal tumors with or without the $\mathrm{CpG}$ island methylator phenotype. Proc Natl Acad Sci USA 97: 710-715, 2000 .

120. Kambara T, Simms LA, Whitehall VLJ, Spring KJ, Wynter CVA, Walsh MD, Barker MA, Arnold S, McGivern A, Matsubara N, et al: BRAF mutation is associated with DNA methylation in serrated polyps and cancers of the colorectum. Gut 53: 1137-1144, 2004.

121. Hawkins N, Norrie M, Cheong K, Mokany E, Ku SL, Meagher A, O'Connor T and Ward R: CpG island methylation in sporadic colorectal cancers and its relationship to microsatellite instability. Gastroenterology 122: 1376-1387, 2002.

122. Shen L, Toyota M, Kondo Y, Lin E, Zhang L, Guo Y, Hernandez NS, Chen X, Ahmed S, Konishi K, et al: Integrated genetic and epigenetic analysis identifies three different subclasses of colon cancer. Proc Natl Acad Sci USA 104: 18654-18659, 2007

123. Munro AJ, Lain S and Lane DP: P53 abnormalities and outcomes in colorectal cancer: A systematic review. Br J Cancer 92: 434-444, 2005.

124. Van Cutsem E, Peeters M, Siena S, Humblet Y, Hendlisz A, Neyns B, Canon JL, Van Laethem JL, Maurel J, Richardson G, et al: Open-label phase III trial of panitumumab plus best supportive care compared with best supportive care alone in patients with chemotherapy-refractory metastatic colorectal cancer. J Clin Oncol 25: 1658-1664, 2007.

125. Heinemann V, Stintzing S, Kirchner T, Boeck S and Jung A: Clinical relevance of EGFR- and KRAS-status in colorectal cancer patients treated with monoclonal antibodies directed against the EGFR. Cancer Treat Rev 35: 262-271, 2009.

126. Boland CR: The molecular biology of gastrointestinal cancer: Implications for diagnosis and therapy. Gastrointest Endosc Clin N Am 18: 401-413, 2008

127. Sinicrope FA, Foster NR, Thibodeau SN, Marsoni S, Monges G Labianca R, Kim GP, Yothers G, Allegra C, Moore MJ, et al: DNA mismatch repair status and colon cancer recurrence and survival in clinical trials of 5-fluorouracil-based adjuvant therapy. J Natl Cancer Inst 103: 863-875, 2011

128. Roth AD, Delorenzi M, Tejpar S, Yan P, Klingbiel D, Fiocca R, d'Ario G, Cisar L, Labianca R, Cunningham D, et al: Integrated analysis of molecular and clinical prognostic factors in stage II/III colon cancer. J Natl Cancer Inst 104: 1635-1646, 2012.

129. Popat S, Hubner R and Houlston RS: Systematic review of microsatellite instability and colorectal cancer prognosis. J Clin Oncol 23: 609-618, 2005

130. Al-Sohaily S, Biankin A, Leong R, Kohonen-Corish M and Warusavitarne J: Molecular pathways in colorectal cancer. J Gastroenterol Hepatol 27: 1423-1431, 2012. 
131. Ribic CM, Sargent DJ, Moore MJ, Thibodeau SN, French AJ, Goldberg RM, Hamilton SR, Laurent-Puig P, Gryfe R, Shepherd LE, et al: Tumor microsatellite-instability status as a predictor of benefit from fluorouracil-based adjuvant chemotherapy for colon cancer. N Engl J Med 349: 247-257, 2003.

132. Sargent DJ, Marsoni S, Monges G, Thibodeau SN, Labianca R, Hamilton SR, French AJ, Kabat B, Foster NR, Torri V, et al: Defective mismatch repair as a predictive marker for lack of efficacy of fluorouracil-based adjuvant therapy in colon cancer. J Clin Oncol 28: 3219-3226, 2010.

133. Yang L, Sun Y, Huang XE, Yu DS, Zhou JN, Zhou X, Li DZ and Guan X: Carcinoma microsatellite instability status as a predictor of benefit from fluorouracil-based adjuvant chemotherapy for stage II rectal cancer. Asian Pacific J Cancer Prev 16: 1545-1551, 2015.

134. Tejpar S, Saridaki Z, Delorenzi M, Bosman F and Roth AD: Microsatellite instability, prognosis and drug sensitivity of stage II and III colorectal cancer: More complexity to the puzzle. J Natl Cancer Inst 103: 841-844, 2011.

135. Des Guetz G, Schischmanoff O, Nicolas P, Perret GY, Morere JF and Uzzan B: Does microsatellite instability predict the efficacy of adjuvant chemotherapy in colorectal cancer? A systematic review with meta-analysis. Eur J Cancer 45: 1890-1896, 2009.
136. De Sousa E Melo F, Wang X, Jansen M, Fessler E, Trinh A, de Rooij LP, de Jong JH, de Boer OJ, van Leersum R, Bijlsma MF, et al: Poor-prognosis colon cancer is defined by a molecularly distinct subtype and develops from serrated precursor lesions. Nat Med 19: 614-618, 2013.

137. Sadanandam A, Lyssiotis CA, Homicsko K, Collisson EA, Gibb WJ, Wullschleger S, Ostos LC, Lannon WA, Grotzinger C, Del Rio M, et al. A colorectal cancer classification system that associates cellular phenotype and responses to therapy. Nat Med 19: 619-625, 2013.

138. De Rosa M, Pace U, Rega D, Costabile V, Duraturo F, Izzo P and Delrio P: Genetics, diagnosis and management of colorectal cancer (Review). Oncol Rep 34: 1087-1096, 2015.

139. Su S, Hu B, Shao J, Shen B, Du J, Du Y, Zhou J, Yu L, Zhang L, Chen F, et al. CRISPR-Cas9 mediated efficient PD-1 disruption on human primary $\mathrm{T}$ cells from cancer patients. Sci Rep 6: 20070, 2016

140. Liao Y, Chen L, Feng Y, Shen J, Gao Y, Cote G, Choy E, Harmon D, Mankin H, Hornicek F and Duan Z: Targeting programmed cell death ligand 1 by CRISPR/Cas9 in osteosarcoma cells. Oncotarget 8: 30276-30287, 2017. 